\title{
胸部X線撮影における補助固定具の考案
}

\author{
獨協医科大学病院放射線部 \\ 牧 野 芳 夫・小黑 清・沢 佳 延 \\ 宇賀神誠・幕 田節 男 \\ （論文受理 1985 年 8 月16日） \\ （最終論文受理 1986年1月14日） \\ (Code No. 423, 496. 1)
}

Key words: Chest-holder, Positioning device, Chest radiography, Bed-patient, Reproducibility

\section{CHEST-HOLDER-A NOVEL POSITIONING DEVICE IN THE CHEST RADIOGRAPHY.}

\author{
Yoshifumi Makino, Kiyoshi Oguro, Yoshinobu Sawa, \\ Makoto Ugazin and Setsuo Makuta
}

Department of Radiology, Dokkyo University Hospital, Mibu, Tochigi 321-02

(Article received, Aug., 16, 1985)

\section{Summary}

Since October 1984, we have developed the "Chest-holder", a novel positioning device for the chest radiography, especially of great benefit for patients with difficulty in standing in an upright position. It consists of three parts: holding-pads, supporting rods, and a simultaneous adjuster.

This device enables the hospital technicians to easily attain the appropriate position of the patient, thereby reducing patient-assistance and X-ray exposure to the radiographic technicians. Furthermore, it was demonstrated that the "Chest-holder" was even useful regarding radiography for normal subjects as it provided great savings in the setup time.

\section{1. 緒言}

胸部X線撮影は，どの施設でも件数が最も多い。とり わけ側面撮影は, 肺門部病変, 綐隔部病巣, 葉間胸膜炎, その他胸郭内異物や病変の位置確認などの解析に欠かせ ない情報を提供するので，正面撮影に劣らず重要といわ
れている゙。

近年，フォトタイマやオートチェンジャの普及により 胸部撮影は容易となり, 短時間で多くの処理が可能とな $\supset た 213$ )

しかしながら，適正な体位を保持できない患者に対し ては，従来の座位や介助などによる方法が必要となる4． 


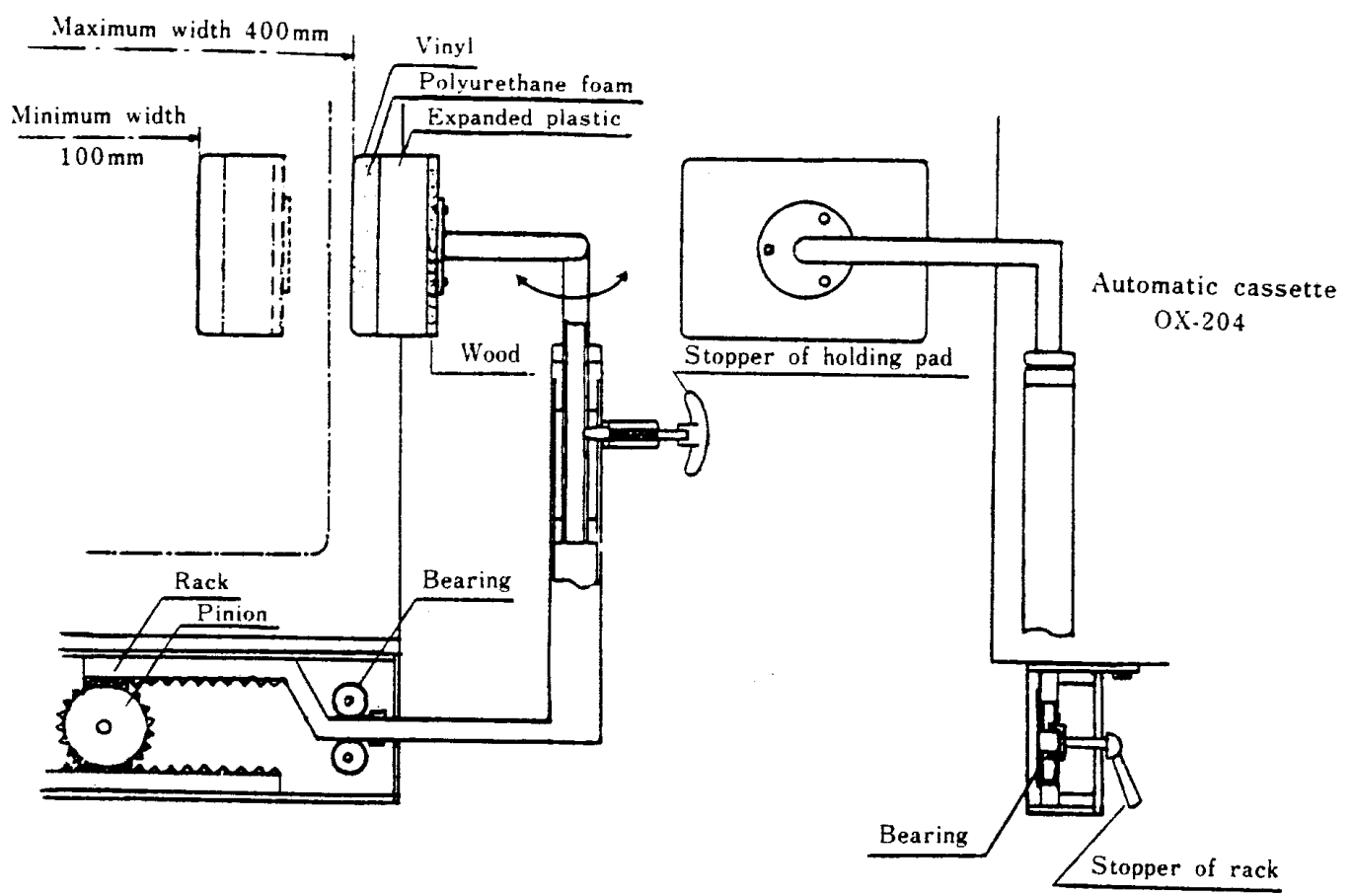

Fig. 1 Dimentional drawings of the "Chest-holder."

特に側面撮影時には，両腕挙上によって患者の状態は， 一層不安定となり介助の頻度も多くなる，その結果，患 者の動きによる，ボケ，フォトタイマ受光部を外れるこ とによる写真濃度の低下および介助者の被曝などに術者 は苦慮してきた。その解決法として, 從来より胸部撮影 時の補助具や固定具に関するものが報告されている が5(6)7), 広く普及していない。

著者らは，先に介助を要せず，正しい体位の保持を可 能とした胸部側面撮影用の補助固定具 1 号機8)を試作し たが，操作性および耐久性が課題となったので，さらに 改良を加六補助固定具 2 号機を試作し踟床に使用したと ころ，その有用性を充分に確認し得たので，その概要を 報告する。

\section{2. 補助固定具 2 号機の構造および機構}

本補助固定具は，当院にある千代田メディカル社製胸 部用オートチェンジャOX-204 型に装着可能で，その構 造図および全景は，Fig. 1, Fig. 2 に示す。

補助固定具本体は，1）固定パット部 (Fig. 2-A)，2）固 定パット部回旋用支柱部（Fig.2-B)，3）左右同幅移動機 構（Fig. 2-C）の 3 つから成る。

\section{1 固定パット部}

患者の体に接触し胸壁を固定させる部分である。材質 は，Fig.1に示したごとく硬質発泡スチロールとウレタ

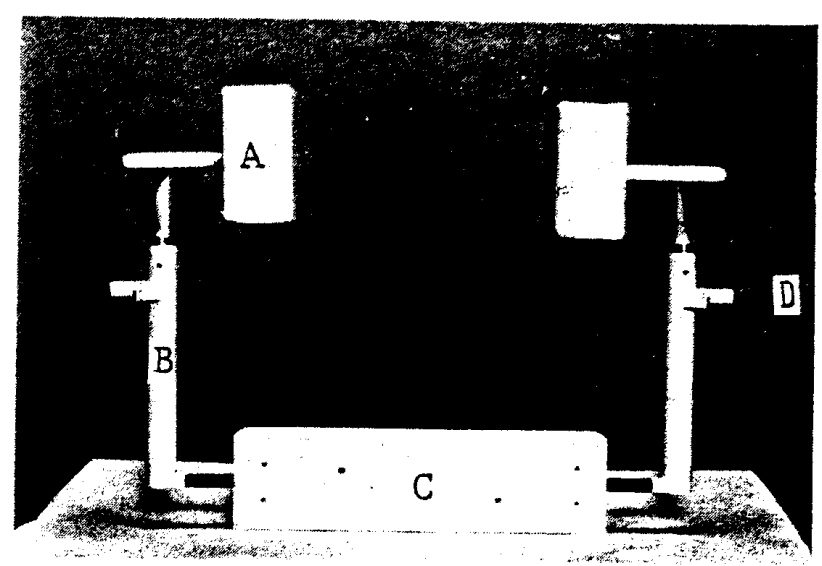

Fig. 2 Whole view of "Chest-holder."
(A) Holding pads
(B) Supporting rods
(C) Simultaneous adjuster
(D) Stopper of holding pads

ン樹脂を使用し木板に接着した。前者は，X線吸収が少 なく軽量で加工が容易であり，また後者は，患者に苦痛 や不快感を与え奴配慮したものである，大きさは， 患者との接触面積を大きくし固定を確実なものとするた め, 縦 $150 \mathrm{~mm} \times$ 横 $200 \mathrm{~mm} \times$ 厚さ $70 \mathrm{~mm}$ とした。また, それらの表面をビニールレザーでカバーし，アルコール 等で拭いて日常使用時に清潔を保てるようにした。 


\section{2 固定パット部回旋用支柱部}

固定パット部を支え左右同幅移動機構に連動する部分 である．固定パット部と直角に固定された内パイプが， 外パイプ内で $360^{\circ}$ 回旋可能なように加工したものであ る. 固定パット部は, ストップレバー（Fig. 2-D）を引く ことによって回旋する，通常の正面撮影時には，側方移 動で撮影操作の邪魔とはならず，一方，固定を要すると きには，固定パット部をフィルム面に垂直にすることに より自動ロック機構が働くので操作が容易である。

\section{3 左右同幅移動機構}

患者の胸厚に合わせて固定パット部を移動させる部分 である，胸部を常にフィルムおよび照射野の中心に位置 付けし，正しいX線の入射を行うために左右固定パット 部の一体化構造を考案した。一体化構造は, ラック(Fig. 1)，(Fig.3-A）とピニオン (Fig. 1)，(Fig. 3-B）から成 り, ベアリング (Fig. 1), (Fig. 3-C) によって, 左右の ラックは円滑に作動する。ネジ式のストッパ（Fig. 4) は，ラックを固定し確実な患者の体位の保持を可能とし
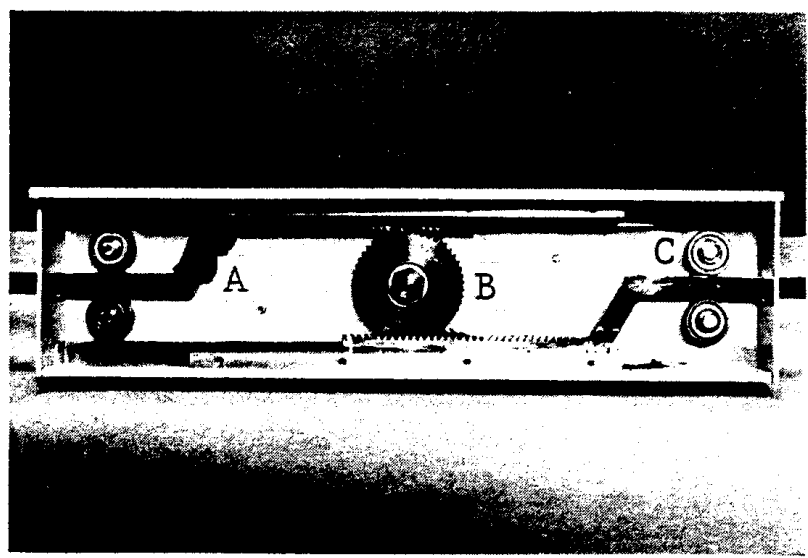

Fig. 3 Simultaneous adjuster.
(A) Rack
(B) Pinion
(C) Bearing

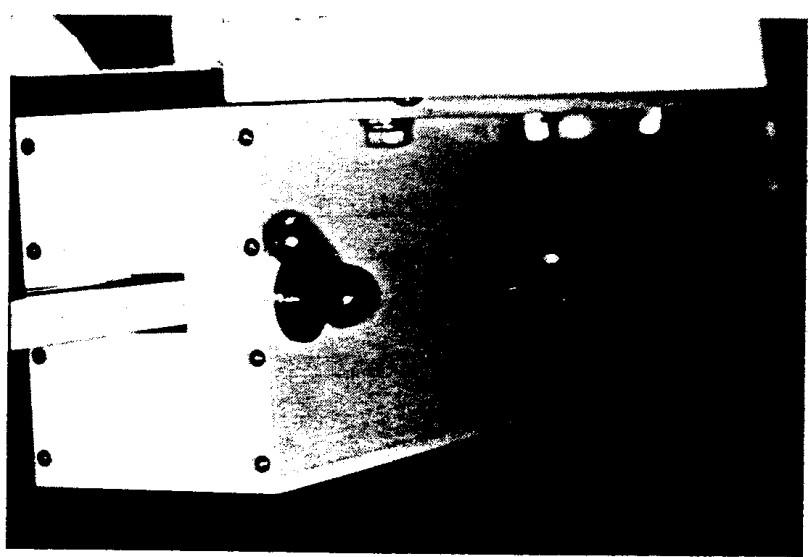

Fig. 4 Stopper of rack.
た。患者の固定幅は， $10 \mathrm{~cm}$ から $40 \mathrm{~cm}$ である。

\section{3. 使用結果}

\section{1 適正体位保持の困難な患者に対する使用}

\subsection{1 正面撮影}

固定具使用に当り固定パット部をフィルム面に垂直の 位置でストップレバーをロックする，体位は，状態が不 安定であるので, Fig.5-a に示すように座位とし, 腰部を
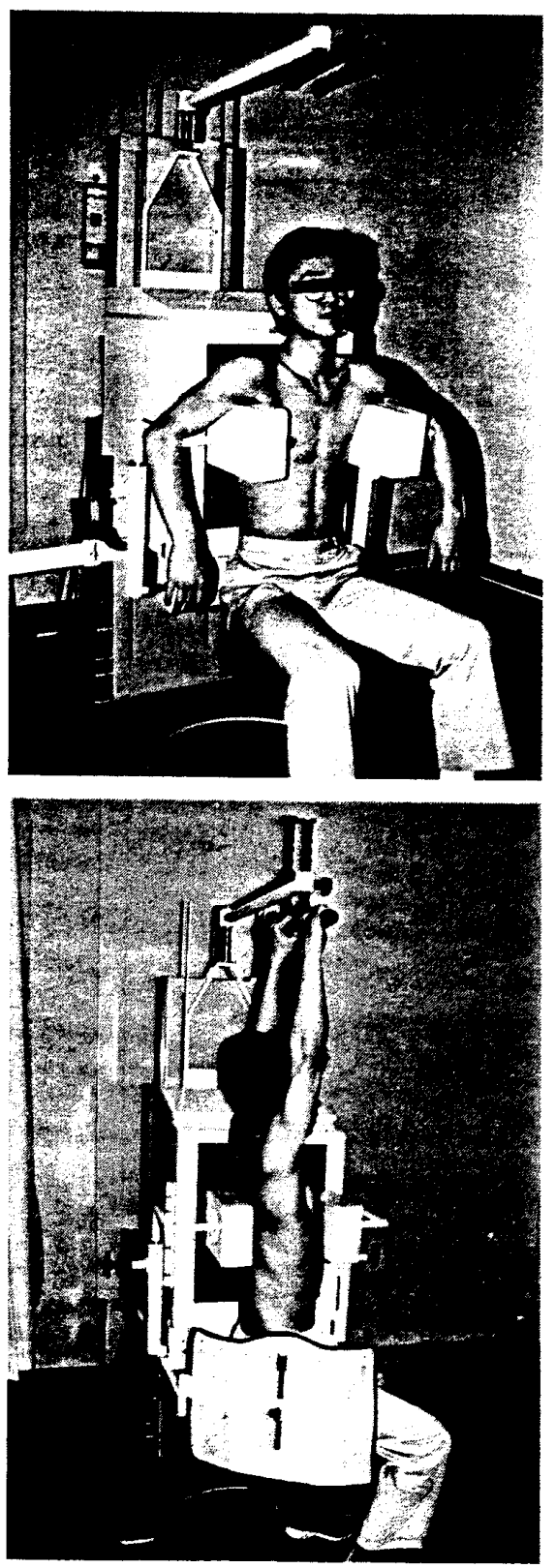

Fig. 5 Chest radiography of a patient showing the difficulty of keeping an appropriate position.
(a) A-P direction
(b) Lateral direction 
フィルム面に付仿，禹脇の下在肘掛け状に固定ハットで 固定する。これにより患者の前後および左右への動きは なく，安定した姿勢で撮影を行うことがごきた。

3.1 .2 側面撮影

Fig. 5-bに示すように正面撮影同様, 座位に上り撮影 を行う．患者に上部グリップを握らせ患者の状態を観察 しながら，胸壁を前後より固定パット部で確実な固定を 行う。 その結果，患者法前後へふらつかず，体位の保持 が行えたこのとき，患者は，照射野の中心より多少前 後していても，固定することで胸部は常に照射野の中心 に位㯰きせることができる。

\section{2 ストレッチャー上での撮影}

ストレッチャで般送される患者は, 体位保持が特に難 しいために，臥位撮影や数名の介助者による撮影が行う れているが, 3.1.1，3.1.2の操作に上り, 正しい正面お よび側面撮影が行えた。

\section{3 健常者における胸部撮影}

側面撮影の操作は, 適正体位保持の困難な患者の撮影 と同様である. 正確性および操作性に優れた本補助固定 具を使用することで, ポジショニング後の患者の動きは 皆無となり，適正体位が即時に得られるので，ポジショ ニングに要する時間は，従来と同等もしくは短縮できた。

また正面撮影では，固定パット部を回旋することで撮 影操作の障害とはならなかった。

\section{4. 考 察}

従来, 胸部X線撮影における補助具使用や固定具試作 の報告は極めて少ない。すなわちポジショニングの再現 性の向上を目的として，患者を立たせる回転台の考察5 や側面撮影時に天井より下げた紐やグリップを㨔ませる 方法”が僅かに一般化しているにすぎない。さらに近年 では，高さ調節の可能な用具を握らせることにより再現 性を増した田中的や補助具自体による絞り効果によって 画質の向上を企った世古”らの報告があるくらいである。 しかしながら, 適正体位の保持が困難な患者の胸部X線 撮影の問題点の解決にはこれまでの方法では㥛めて不 十分であり，そのような基本的技術面に言及した報告は 全く見当らない.

そこで著者らは，適正体位保持の困難な患者を対象と した胸部X線撮影用補助固定具 1 号機を試作し，1984年 10月より発表した ${ }^{8)}$. その際の補助固定具製作の設計は 次のような点を考虑した。

1）操作が容易かつ円滑であること.

2）耐久性おょび強度に優れていること。
3）固定が正確かつ確䒠に行える機構であること。

4) 固定に際し患者汇苦痛を与え奴構造であるこょ。

万）固定ハット部のX線吸収が少なく陰影とならるここ。

6）再現性に侲饥ていること。

7）健常者の撮影にも有用であるこょ。

しかし、この1号㙨については，実際の診療使用およ び学会での質疑なよ゙により操作性と耐及性に課題が有り とされだ)ので, それら在改良した試作補助固定具 2 号 㙨を1984年12月に作製した ${ }^{91}$. 試作 2 号機の具体的な改 良点は，耐久性を高めるためにスチールを採用したこと， さらにフィルムおよず照射野の中心で胸部の固定を容易 にするためにラックとピニオンの左右同幅移動機構を取 り入れたことである. 現在まで, 日常診療 5,000 例以上に 使用し有用性を認め，上述の設計条件1)〜7)の全てを満 たしていることが確認された.

すなわち，座位やストレッチャ上での正面わよで側面 撮影時には, 患者の前後左右への動きは消失し介助の必 要性が大幅に減り術者の被曝を軽減させた。 また，正確 かつ確実な固定が常時可能なため, 患者の動きに伴うボ ケや患者のフォトタイマ受光部からの外れがなくなると 上もに，常に同様のポジショニングにより再現性が向上 し患者の状態の経時的変化の観察にも有用であった。き らに左右同幅移動機構の改良は, 操作を極めて容易なも のとし, その結果, 健常者の胸部撮影においてもポジシ ヨニングに要する時間を従来と同等もしくは短縮するな どの有用性も確認し得た。

\section{5. 結論}

胸部撮影における本補助固定具の特徵は，確実な固定 を行うことで適正な体位を得られることである。これは， 常に照射野の中心に患者を位置させる左右同幅移動機構 と操作性や耐久性に優れた固定パット部回施用支柱部に ある。この補助固定具の使用により介助を要するような 状態の不安定な患者に対しては, 介助を要せず正しい体 位での撮影が容易となり，さらに健常者に対しても正確 なポジショニングが即時に得られる。

したがって，1)正確な撮影体位の保持，2)経時的変化 の観察にも適する偦れた再現性，3）介助者の被曝の軽減， 4)ポジショニングに要する時間の短縮など, 臨床の撮影 技術の向上掞よび診断価値への貢献が日常診療上奏証さ れた。

\section{6. 謝辞}

稿を終えるにあたり, 御指導, 御校閲を踢わりました獨協医 
科大学放射線医学教室兵頭春夫教授、仲澤聖則講師ならびに補 助固定具の製作に御協力を頂きました千代田メディカル株式 会社近藤和男氏，島村千加志氏に樑く感謝致します。

この論文は，1985年 4 月 6 日，鹿児島で行われた第41回日本 放射線技術学会総会において発表したものである.

\section{文献}

1）立人弘：一般撮影法，診療放射線技術上巻，p. 168171，南江堂，東京，（1978）。

2) 青柳泰司：放射線機器学, 日本放射線技術学会編, p. 205-212, 通商産業研究社, 東京, (1979).

3）青柳泰司：診断用 X線装置，p. 379-380，コロナ社, 東京, (1979).

4）岡崎長, 藤木幹雄：X線写真撮影用具について, Positioning の補助用具, 日放技学誌，22(3)，2425, (1966).
5) Clark's positioning in radiography, ed. by Louis Kreel 10th ed, Vol. 1, Williem Heinemann Medical Book Ltd, London. 333-369, (1979).

6）田中裕之, 古川隆志, 砂屋敷忠：胸部撮影時の補助 具試作と使用経験, 中四国部会予稿集, 29 , (1982).

7) 世古勝彦，大村博信：胸部側面撮影の補助具につい て，第41回日本放射線技術学会総会予稿集，348349 , (1985).

8）幕田節男，小黒清，牧野芳文，他：胸部撮影におけ る試作固定具, 第31回関東東京部会予稿集, 24 , (1984).

9）牧野芳文，小黑清，宇賀神誠，他：胸部側面撮影に おける固定具の考案，第41回日放技学会総会予稿集， 350-351, (1985). 